\title{
UNIVERSITEIT IN AANVRAAG
}

\author{
1. ...das Festhalten an der Universitätsidee \\ erscheint als romantisches Träumen. ${ }^{1}$ )
}

Die geskiedenis van die Wes-Europese universiteit is in 'n bepaalde opsig vergestalting van sy worsteling om eenheid en samehang in die wetenskappe. Selfs die historiese lyne insake die verhouding tussen universiteit (studium) en kerk (sacerdotium) in die Middeleeue is aanduiding van hoe gedink is oor Filosofie (wete) en Teologie (geloof) as totaliteitswetenskappe in ensiklopediese $\sin$. By die vraag hoe die samehang van die wetenskap te waarborg is, het 'n "Streit der Fakultäten" nie uitgebly nie. Die vraag na die univertas gee steeds aanleiding (of ' $n$ poging) tot 'n nuwe wetenskapsindeling.

Byna oral in ons Westerse wêreld beleef die universiteit 'n uitbreiding en groei in sy geboue, laboratoria, institute, boekery, leerstoele, dosente- en studentetal, ens. Steeds dringender word in byvoorbeeld Duitsland, Nederland, Engeland en Suid-Afrika die kreet om meer wetenskaplikes (veral natuurwetenskaplikes en tegnoloë), meer vakkundige spesialiste, meer professioneel opgeleides, meer leiers, meer universiteite gehoor.

Waarom is daar so 'n drang na die universiteit? Wat verskaf die universiteit, wat word van die universiteit verwag, wat behoort die universiteit te verskaf dat dit so in aanvraag is?

'n Konstatering met genoeg trefkrag is: Die universiteit is druk onder bespreking veral vanweë die bestellings of eise van die samelewing.

Die universiteit word nie opgesoek omdat dit die samehang van die wetenskappe in hulle navorsing en onderrig deursigtig mak nie. Die universiteit is in aanvraag omdat dit beskou word as ' $n$ middel tot beroeps- 
opleiding. ${ }^{2}$ ) In menige universiteitsbrosjure word dié inrigting vir hoër onderwys gepropageer by wyse van sy sg. „beroepsvakke”. Dit word nie in die eerste plek gepropageer as 'n inrigting vir hoër onderwys nie. Dit word meestal só geadverteer dat die publiek tevrede gestel word met die indruk dat dit ' $n$ handige instituut tot opleiding in sosiaal-verhewe beroepe is. ${ }^{3}$ )

Die universiteit is in aanvraag omdat dit "gesosialiseer", ,vermaatskaplik" is. Dit is leweransier vir die maatskappy. Van die universiteit word verwag om by te wees met die tyd en omstandighede. Van die universiteit word verwag om oplossing te gee aangaande groot lewensvrae. Die universiteit moet aanpas by en gebaseer wees op ,the practical needs of a changing world". ${ }^{4}$ ) Ook die studies moet sodanig ingerig wees. „You cannot learn everything; the objects of knowledge have multiplied beyond the power of the strongest mind to keep pace with them all. You must choose among them, and the only reasonable guide to choice in such matters is utility".5) Die student sien die universiteit in die lig van die beginsel: "the shorter learning, the sooner earning".6) Volgens Moberly lewer hierdie moderne „utility"-universiteit net wat u bestel: wil u ' $n$ katedraal, dit kan u kry; wil $u$ verbetering van die bemesting, ook dít kan; verkies $\mathbf{u}$ 'n waterstofbom en eerstehulp, ook dít word verskaf.

2. De crisis van de universiteit is dan ook voor een zeer belangrijk deel enerzijds de weerstand van alle andere krachten tegen dit nieuwe universiteitstype, anderzijds de wrevel dat de ontwikkeling zich niet snel genoeg voltrekt en dat de universiteiten nog steeds goeddeels leven in een onwerkelijke wereld, in de geschiedenis of de bespiegeling. ${ }^{\text {) }}$

Baie van diegene wat voorstanders is van ' $n$ ander gedagte as dié van die vermaatskaplikte universiteit sal byvoorbeeld die universitätsgedagte van J. S. Mill gelyk gee as hy sê: „What professional men should carry away from an University, is not professional knowledge, but 
that which should direct the use of their professional knowledge, and bring the light of general culture to illuminate the technicalities of a special pursuit". ${ }^{8}$ )

Diegene wat instem dat die universiteit altyd die praktyk met sy navorsing moet dien, dat die man van wetenskap steeds by al sy ondersoekinge die gemeenskap of samelewing voor oë moet hou, bly ook 'n antwoord verskuldig op die vraag wat hoër onderwys ten opsigte van die verband van die wetenskap is. Hierdie antwoord is ook vir die student van betekenis. „The haunting trouble of the student to-day is a very deepseated doubt whether in the modern world, so impersonal and so insecure, his life can have any significance".9) Beter gestel: elke universiteit in ons geskiedenis gee nolens volens daarop antwoord.

3. A studium was quite simply, a place of study, a place where organized teaching and learning went on. $\left.{ }^{10}\right)$

Vir die Middeleeuse universitas magistorum et scholarium was daar vier fakulteite:

(i) die "facultas artium" wat 'n voortsetting van die Romeinse „trivium" (grammatika, retorika en logika) en "quadrivium" (musiek, aritmeti$k a$, geometrie en astronomie) was;

(ii) die teologiese fakulteit;

(iii) die regsfakulteit;

(iv) die mediese fakulteit. ${ }^{11}$ )

Tesame het die vier fakulteite die studium generale of universiteit gevorm. Die "generale" wil sê dat die "studium" bestem is vir alle daartoe geskikte leerlinge uit alle nasies, en nié dat alles onderrig word nie.12)

Die universiteit wat in die 14e eeu oorwegend kortweg studium genoem is, het reeds 'n honderd jaar na sy ontstaan gedurende die twaalfde eeu 'n groot mag naas kerk en staat gevorm. ${ }^{33}$ )

Die „universitas" wat aanvanklik 'n gilde van professore en studente aandui, het eers vanaf die $15 \mathrm{e}$ eeu be- 
trekking op die geheel van die wetenskappe as universitas scientiarum..$^{14}$ )

Wat was die waarborg van die geheel van die wetenskappe?

Ten opsigte van die ensiklopedie van die wetenskappe, was die "facultas artium" die basis-fakulteit. Die "artes liberales" (grammatika, retorika, logika, musiek, aritmetika, geometrie en astronomie) was 'n propede u t i e s e studie tot die spesialisasie in Regte, Teologie en Medisyne. ${ }^{15}$ ) Die sewe vakke van die basis-fakulteit is „artes liberales” genoem, nié omdat dit dan sg. „vrye kunste" was nie, maar omdat dit 'n vrye man (nie 'n slaaf nie) betaam het om hierdie ,artes" te volg.16)

Wat die grondslag van die betrokke wetenskappe betref: „De algemene geestelijke achtergrond van die universiteiten was het Corpus christianum".17) Maar daarmee was die probleem wete/geloof nie vir die Middeleeuse universiteit uit die weg geruim nie. Of laat ons dit oor 'n ander boeg gooi: die Corpus christianum was normatief vir die wetenskapsbeoefening, maar die wetenskappe was feitelik nie eenduidig Christelik nie. Dit het ook voorgekom dat die kerk homself destyds as die Corpus christianum verstaan het en so as hoeder van integrasie in die wetenskap probeer optree het.

Beroemd is die voorbeeld van die stryd in 1255 om die Aristotelisme in Parys "naar aanleiding van het kerkelijk verbod van het werk van abt Joachim van Fiore uit Calabrieë. De toen nieuwe bedelorden, met name de Dominicanen, leidden de actie onder het schild van Aristoteles. De Paus dwingt hun toegang binnen de muren van Parijs af. Maar in de volgende fase zijn het weer de Dominicanen met Thomas van Acquino voorop, die er leerde, die zich tegen een integraal aristotelisme, tegen het averroïsme verzetten. In 1277 behaalde Thomas posthuum de zege in deze geweldige strijd en sindsdien werd op de duur het Thomisme ... de officiële kerkelijke filosofie. Van die tijd af wordt de facultas artium ook een filosofische faculteit, waaraan onze naam faculteit van letteren en wijsbegeerte nog steeds herinnert". ${ }^{18}$ ) 
4. Die ratio erobert sich im ganzen Kulturleben so stark die Herrschaft, dasz diejenige Fakultät, die lange Zeit nur die Pflicht hatte, unter dem Namen facultas artium propädeutische Arbeit zu leisten, sich nun langsam in die „Philosophische Fakultät" verwandelt, die die Prinzipien aller Wissenschaften entwickelt. ${ }^{19}$ )

Hier is meer op die spel geplaas as net 'n naamsverandering. Die universitasgedagte is op die spel. In die eerste plek word die propedeutiese fakulteit, lewens- en wêreldbeskoulik gesien, nou Thomisties gelaai. ${ }^{20}$ ) Dit was die wegbereider vir die latere (veral weer in die $20 \mathrm{e}$ eeu sterk bepleite) beskouing waar Filosofie gelyk gestel is aan ideologie of lewens- en wêreldbeskouing.

Die skolastiese Wysbegeerte is gesien as ,den tragende Grund aller Einzelwissenschaften". ${ }^{21}$ )

Tweedens het dit beteken dat die leer van die twee ordes, ' $n$ redelike (natuurlike) en bo-redelike (genade) orde, gepredik is. Die Rooms-Katolieke ideologie het geleer dat die redelike Wysbegeerte outonoom op sy gebied (universiteit) is en neutraal ten opsigte van die vraagstukke van sonde, genade, geloof, ideologie, ens. (kerk) staan. Geloof is sodoende vir die kerk gereserveer en wetenskap aan die universiteit toegesê..22)

Die universiteit is 'n outonome universitas scientiarum.

Daarmee het in die derde plek die sekularisasie van die universiteit en wetenskap ten opsigte van die kerk en die Christelike leer in snelheid toegeneem - en dit teen die bedoeling van die kerk in. Hierdie gebeure het die weg gelyk gemaak vir die omstandigheid in die $18 \mathrm{e}$ eeu dat die Wysbegeerte as sg. redewetenskap self moes uitmaak watter wêreldopvatting die juiste is.

Die idee van die outonomie van die (veral profane) wetenskap is bepalend vir die ontstaan van die sg. neutrale universiteite in die $19 \mathrm{e}$ eeu. Elke afhanklikheid van 'n ideologie of Teologie word van die hand gewys. Veral in Duitsland (Halle) word die beginsel van libertas philosophandi erken. Daarmee is uiteindelik bedoel die sg. vryheid om 'n eie oortuiging te vorm. ${ }^{23}$ ) 
Die idee van 'n neutrale universiteit het die liberale staat van dieselfde eeu uitstekend gepas en „de liberale staat bemoeit zich niet met de Universiteit alleen daarom niet, omdat het niet nodig is en het is niet nodig, omdat er alleen liberale professoren zijn". ${ }^{24}$ )

Hierin het tans 'n verandering gekom.

Die sg. neutrale universiteit het die ganse universitasgedagte getorpedeer. Van hierdie sg. universiteit kan gesê word dat dit 'n "niet-universiteit" ${ }^{25}$ ) is.

„Die Christen sien die moderne liberale universiteit as 'n versameling van mense sonder enige gemeenskaplike oortuiging, lewens- en wêreldbeskouing, van mense wat die mees onverbonde spesialismes nastreef en wat hul sg. ,neutraliteit” gebruik as 'n verskoning om alle fundamentele en betwisbare vraagstukke te vermy... In 'n liberale universiteit sien die Christen nie afwesigheid van oortuiging nie maar ' $n$ verwarrende verskeidenheid van botsende oortuigings, wat alle eenheid van optrede, alle eie karakter onmoontlik maak. Wat $\mathrm{A}$ leer, word deur B bestry." ${ }^{26}$ ) Die universiteit het soek geraak.

„Streng gesproke is die ,neutrale' universiteit ook 'n besondere universiteit, en wel in dié sin dat sy ideaal om alle standpunte en stromings welkom te heet en 'n standpuntstryd binne eie geledere te begunstig, konsekwenterwyse slegs op 'n liberalistiese standpunt gehandhaaf kan word, ook al sal dit inkonsekwenterwyse ook nie-liberaliste tot sy geledere verwelkom. Ook hieruit blyk dat universiteit en wetenskap aan die een kant en lewens- en wêreldbeskouing aan die ander kant nie van mekaar geïsoleer kan word." ${ }^{27}$ )

\section{Op soek na die universiteit.}

In die twintigste eeu vind ons ook 'n opkoms van die Christelike universiteit wat die universitasgedagte soek vanuit 'n Christelike lewens- en wêreldbeskouing.

In die twintigste eeu kom daar verskeie nie-neutrale konsepsies na vore wat die universitas scientiarum veral soek in die diens - hetsy kultureel of professioneel aan die samelewing. Hierdie beskouinge doen hulle as nie- 
neutraal voor, omdat hulle die wetenskap juis betrokke sien by die beroepswêreld en die behoeftes van die samelewing, omdat hulle die mens wat die wetenskap uitbou self daarby ingeskakel sien.

Die twintigste eeuse universiteit het ook met 'n „streng requisitoir"28) oor homself in sy predisposisies, erfgoed en take begin. Sonder om die klagtes wat mekaar dikwels weerspreek hier te enumereer, gee ons 'n aanduiding van die vernaamste probleme waarmee die huidige universiteit worstel.

Wat is die gevolge van die hedendaagse voortskrydende spesialisasie in die wetenskap? Herberg dit nie 'n gevaar van oorspesialisasie in die wetenskap, waardeur 'n isolasie tussen wetenskap en wetenskap tot stand kom en waardeur 'n verbrokkeling van die eenheid van die wetenskap as geheel in die hand gewerk word nie ${ }^{29}$ ) Kan 'n juiste beoefening van 'n wetenskap geïsoleerd van ander wetenskappe en los van die verband tussen wetenskap en lewe plaasvind?

Naas spesialisasie beklemtoon vele universiteite die betekenis van een of meer kursusse wat die samehang van vakke en die betekenis van die samehang vir die praktyk na vore bring. Hoe kan die student spesialiseer sonder om sy terrein van ondersoek van ander te isoleer en hoe kan hy sonder oppervlakkigheid sy gespesialiseerde vakkennis integreer met die wetenskap en lewe as geheel? Watter wetenskapsindeling en selfs nuwe fakulteitsindeling kan hier help?

Word die huidige universiteit al meer 'n tegniese instituut vir beroepsopleiding? Wat moet verstaan word onder navorsing en onderrig as akademiese taak van die universiteit? Word die akademiese taak verwaarloos of gedevalueer tot 'n middel vir tegniese bekwaamheid?

Is dit nie van belang vir die behartiging van 'n latere beroep dat - saam met die professionele opleiding veral ook aandag gegee word aan 'n meer algemene akademiese vorming of aan 'n ,general education" van die student nie? 
Verskeie universiteite besef dat hulle as kultuursentrum aan die samelewing integrale leiers moet gee nie net gespesialiseerde vakkundiges nie. Maar indien dit nie voldoende is om die student uitsluitlik professioneel te vorm nie, wat moet in hierdie verband dan die aard van die akademiese vorming van die student wees?

Word die huidige universiteit gedwing om - dikwels op grond van groot skenkings van byvoorbeeld werkgewers en industrialiste - al meer sekere beroeps- en groepsbelange in die samelewing te bevoordeel? Is dit so dat die universiteit sy akademiese vakke begin interpreteer en adverteer in terme van sg. beroepsopleiding?

Dergelike vrae en nog meer is deur verskeie universiteite met dikwels uiteenlopende oplossings tegemoetgegaan. Die University of Keele (1962) in Engeland het sedert sy stigting in 1949 as University College of North Staffordshire in die hele Westerse wêreld bekendheid verwerf met sy „experiment in general education". Dit trag om met behulp van veral 'n "foundation year" iets terug te wen van die tradisionele propedeutiese fakulteit. Met die oprigting was daar twee doelstellings: „firstly to try to provide a curriculum which would include a corrective to the prevailing departmentalism of University teaching; and, secondly, but more importantly, to aim at producing graduates who, by pursuing an integrated course of study in which specialisation along one line of enquiry is backed by more general studies, might be expected to glimpse the interconnectedness of all branches of human enquiry, and experience the sense of belonging to a community of scholars privileged to exercise their varying talents, but obligated to serve the needs of the wider community by acquiring the knowledge and skill required to close the gap between the natural leader and the specialist. The College was to serve as a means of re-uniting a society divided as much by lack of a common medium of communication as by industrial strife, political and religious differences". ${ }^{30}$ )

„The minimum period of study prior to the awarding 
of the Bachelor's Degree is four years. The period of four years is divided into two parts.

(a) A first year course, consisting of a common course of lectures for all students, with tutorial work adapted to individual needs (Foundation Year).

(b) A three-year course of studies in selected subjects." ${ }^{31}$ )

"The first year course is based upon a series of lectures in which all the Professors take part. They are designed as a whole to introduce the student to some of the methods and information necessary to an estimate of the inheritance, the problems and the achievements of modern Western European man." ${ }^{32}$ )

"The object of the first year's studies is to develop in the student, at the outset, some appreciation of the nature and interconnections of the main branches of university studies." ${ }^{33}$ )

Die University of Sussex (1961) wyk ook van die beproefde Oxbridge-patroon af en trag om met behulp van nuwe vakgroepering die universitas scientiarum te vergestalt. „The curriculum is designed to provide undergraduates with the combined benefits of specialised and general education. The University is organised not in departments but in Schools of Studies, each with a Dean as Chairman. In each School undergraduates specialise in some particular discipline - their major subject but they also share certain common subjects with undergraduates majoring in other subjects. This study of common or contextual subjects is designed to acquaint undergraduates with different approaches to learning, to show how different subjects are related to each other, and to reveal how they are applied in the modern world." ${ }^{34}$ ) Hier word dan gepraat van ,the School of English and American Studies", „the School of Physical Science", ens.

6. Disagreement concerning the purpose of a university leads to disagreement concerning what it shall teach and how subjects shall be taught. ${ }^{35}$ ) 
Aan 'n universiteit met 'n Christelike (protestantsCalvinistiese) lewens- en wêreldbeskoulike basis word die samehang van die wetenskap by uitstek gerealiseer vanuit die Christelike uitgangspunt wat bepalend is vir elke wetenskap in sy spesialiserende bedrywigheid. In hierdie opsig sal goeie spesialisasie tendeer na integrasie. Die Christelike standpunt kan ook nie losgemaak word van die beoefening van die betrokke wetenskap nie. Daarom behoort die Christelike universiteit nie voor 'n dilemma te staan te kom wat soos volg geformuleer is nie: „Het is eenvoudig een onmogelijke toestand, wanneer in de moderne universiteit de theoloog, de psycholoog en de medicus-bioloog zich met het verschijnsel mens bezighouden, zonder gealarmeerd te worden door het uitblijven van ook maar de geringste poging om zich onderling rekenschap te geven, waar zij het over hebben". ${ }^{36}$ )

Waar geen eenheid van geloofsbeskouing rakende die betreffende terrein van ondersoek bestaan nie (soos aan 'n neutrale universiteit voorkom), kom isolerende en botsende spesialismes tussen die verskillende vakgebiede voor. Hierteenoor kan ons die gedagte van die Christelike universiteit só stel: 'n spesialisasie vanuit Christelike standpunt tendeer na integrasie van die wetenskappe ook wat hulle metodes, probleemstellings en resultate betref.

Wat die ensiklopedie van die wetenskap betref, is daar ook 'n (o.a. vakfilosofiese) samehang. Interdissiplinêr gesien, vorm die wetenskap ook 'n samehang in byvoorbeeld die wisselwerking (uitruil van gegewens) en saamwerking van wetenskappe. Maar om te dink dat die universitas scientiarum gewoon saaklik (neutraal) interdissiplinêr en ensiklopedies uitgewerk kan word (deur bv. 'n kursus wat dikwels "studium generale" genoem word of deur die opset van 'n "foundation year"), is 'n vergissing. Korrek, die wetenskaplike moet meer-dimensioneel dink. Maar as die meer-dimensionele denke of "different approaches to learning" nie op hul beurt deur 'n eenheidsgrondslag gedra word nie, sal ook dít misluk. Meer-dimensionele denke sonder meer is self fragmenta- 
ries en abstrak en kan nie tot ' $n$ eenheidsvisie lei nie. 'n Kursus soos Studium Universale aan die P.U. vir C.H.O. bedoel dan ook om integrasiefaktore te ontgin vanuit die gemeenskaplike basis.

Oorbekend is pleidooie vir die instelling van 'n sg. sentrale fakulteit wat 'n kyk op die sin van die lewe moet verskaf (Ortega y Gasset c.s.) of vir die instelling en/of omvorming van fakulteite en departemente wat eerder 'n karaktervormende, geestelike en kulturele taak het as wat dit sou oplei vir 'n professie of selfs sou spesialiseer in vakkundigheid. Dergelike pleidooie veronderstel dat een deel van die wetenskap ' $n$ vormende of opvoedende waarde het (t.o.v. veral karakter, etiese gedrag, sosiale relasies) - kortom: dat dit ' $n$ ideologie of lewensoortuiging verskaf - en dat die ander deel van die wetenskap jou vakkundig bekwaam en voorberei vir 'n beroep en daarom enkel saak van kennis, geleerdheid en denkvaardigheid is.

Besware hierteen kan opsommenderwys soos volg gestel word:

Sodanige voorstelle ly nog onder die veronderstellings van die sg. neutrale universiteit - asof daar 'n deel van die wetenskap sou wees wat los van 'n ideologie beoefen kan word. As die een fakulteit of departement die lewens- en wêreldbeskoulike beginsels verskaf en beliggaam, hoe beoefen mens die wetenskap in die ander afdeling - neutraal? Selfs die departemente Studium Universale en Filosofie aan 'n P.U. vir C.H.O. kan nie gesien word as die waarborg van die Christelike karakter van die res van die departemente aan dié Universiteit nie. Die Christelike beoefening van die vak is integrale deel daarvan en kan nie as annex daarnaas (bv. in ' $n$ afsonderlike departement) geskied nie - want hoe geskied die beoefening van die vak dan self?

Tweedens: alle wetenskappe aan 'n Christelike un1versiteit is ,ideologies" bepaald. Ons mag nie mislei word deur die historiese omstandigheid waar Filosofie gelyk gestel is met ideologie nie. ${ }^{37}$ ) Filosofie is 'n wetenskap met ' $n$ bepaalde terrein van ondersoek soos enige ander 
wetenskap en dit word konstitutief uitgebou op grondslag van 'n bepaalde ideologie soos enige ander wetenskap.

Derdens herhaal ons wat in verband met die University of Keele en die University of Sussex hierbo ter sprake gekom het: hoe kan die universitas scientiarum deur een afdeling in die wetenskap gehandhaaf word as dit self geen eenheidsgrondslag besit nie?

In die vierde plek maak ons beswaar teen die gedagte dat een of ander wetenskap (byvoorbeeld Filosofie of Teologie) die mens van 'n lewens- en wêreldbeskouing, ideologie of geloof sou voorsien. ${ }^{38}$ ) Dit is 'n verkapte rasionalisme waarvolgens die menslike rede in staat sou wees om te beslis oor die vraag watter geloof, lewensen wêreldbeskouing en ideologie die juiste is. Hiermee het ons ons ook gekeer teen die standpunt dat Filosofie die wetenskap sou wees wat die „Prinzipien aller Wissenschaften entwickelt" ${ }^{\prime \prime}{ }^{9}$ ) Ook daarom kan die naam van daardie departement wat onder andere handel oor beginsels en metodes in die wetenskap nie verander word tot Filosofie of Spesiale Filosofie of Teologie of Spesiale Teologie of Leke-Teologie nie! ${ }^{40}$ )

Vyfdens lê die universitasgedagte ook daarin dat alle akademiese vakke "vormend" en „voorbereidend" van aard is. Die opleidingswaarde van sommige wetenskappe wat kwansuis geen "beroepsvakke" ${ }^{41}$ ) sou wees nie, is juis dat die student só voorberei word dat hy van daaruit selfstandig en verantwoordelik kan dink en handel in 'n toekomstige beroep. ${ }^{42}$ )

Hiermee het ons nie die laaste woord gespreek in verband met die „vermaatskaplikte” universiteit nie. Vrae soos: is die universiteit ' $n$ beroepsinstituut of ' $n$ inrigting vir wetenskaplike ondersoek en onderrig; behoort die wisselwerking tussen universiteit (wetenskap) en samelewing (beroep, bedryf, staat, ens.) slegs dié van nuttige toepasbaarheid van die wetenskap te wees? - kan hier alleenlik gestel word. Die voorafgaande mag 'n aanduiding gee waarom ons wetenskap nie gelykstel met toegepaste kennis en beroepskennis nie.

P. G. W. du Plessis. 


\section{P.U. vir C.H.O.}

1) FLITNER, W.: Situation und Aufgabe der Universität, art. in Universität und moderne Welt; ein internationales Symposion. Herausgegeben von Richard Schwarz, Walter de Gruyter \& Co., Berlin, 1962, p. 30: Die vaskleef aan die universiteitsidee blyk romantiese drome te wees.

2) Vgl. VAN DER LEEUW, G.: De crisis der universiteit, art. in Wending, jaargang 5, no. 11, Jan. 1951, p. 606.

3) Vgl. GUARDINI, R.: Die Verantwortung des Studenten für die Kultur art. in Die Verantwortung der Universität, drei Vorträge von Romano Guardini, Walter Dirks, Max Horkheimer. Im Werkbund-Verlag, Würzburg, 1954, p. 7 e.v.

4) MOBERLEY, W.: The crisis in the university, S.C.M. Press Ltd., London, $1949^{2}$, p. 71.

5) GRIERSON, H.: The university and a liberal education. Oliver \& Boyd, Edinburgh/London, s.d., p. 3.

6) MOBERLY, W.: a.w., p. 24.

7) VAN DER LEEUW, G.: a.w., p. 607

8) CLAPP, M. (ed.): The modern university, Cornell University Press, Ithaca/New York, 1950, p. 43.

9) MOBERLY, W.: a.w., p. 73.

10) DENT, H. C.: Universities in transition, Cohen \& West, London, 1961 , p. 16

11) Vgl. POLAK, F. L.: Het hoger onderwijs, op de helling of op een hellend vlak? A. W. Sijthoff, Leiden, 1961, p. 51

12) Vgl. DIEPENHORST, I. A.: De geprangde universiteit, Kemink \& Zoon N.V., Utrecht, s.j., p. 9 voetnoot 2.

13) Vgl. DEMPF, A.: Die Idee der Universität, art. in Universität und moderne Welt, $\mathrm{p} .11$.

14) Vgl. ROMEIN, J. M.: Universiteit en maatschappij in de loop der tijden, E. J. Brill, Leiden, 1947, p. 5.

15) Vgl. COETZEE, J. C.: Die Christelike universiteit. Oordruk uit Koers, April 1954, Potchefstroom, p. 25; CLAPP, M. (ed.): a.w., p. 4 \& 5.

16) Die Renaissance-Humanisme en die 19e eeuse Liberalisme het hiervan iets anders gemaak, nl. dat die sewe artes ,liberaal" (d.i. neutraal) bestudeer en doseer moet word. Oorspronklik hou ,artes liberales" verband met Griekse en Romeinse "concepts of education befitting free men".

Kyk STATE EDUCATION DEPARTMENT: Glossary of terms, University of the State of New York, June 1961, p. 57.

17) VAN DER LEEUW, G.: a.w., p. 605.

Vgl. ook COETZEE, J. C.: a.w., p. 2.

18) ROMEIN, J. M.: a.w., p. 8-9.

19) SPRANGER, E.: Gestalt und Problematik der deutschen Universität, art. in Universität und moderne Welt, p. 208. 
Kort saamgevat heet dit: Die Filosofie het as redewetenskap so beheersend geword in die facultas artium, dat $\mathrm{lg}$. in 'n Filosofiese fakulteit verander het wat die beginsels van alle wetenskappe uitwerk.

20) Vgl. DIEPENHORST, I. A.: a.w., p. 10;

BARION, J.: Universitas und Universität, Ludwig Röhrscheid Verlag, Bonn, 1954, p. 10-11.

21) SPRANGER, E.: a.w., p. 212-213.

22) „The question then immediately arises: why then did the church try to control the university? The answer to this question lies in Thomas Acquinas' compromise with Greek culture and the philosophy of Aristotle in the idea that the autonomy of the two sides (science and religion, nature and super-nature, reason and faith) must be balanced by their synthesis, in order to prevent open contradiction between the two..."

Kyk VAN DEN BORN, Wm.: History and development of the university, art. in The Vanguard, vol. 4, no. 6, Nov. 1962, p. 5.

23) Vgl. STOKER, H. G.: Beginsels en metodes in die wetenskap, Pro Rege, Potchefstroom, 1961, p. 15.

24) ROMEIN, J. M.: a.w., p. 16

25) Volgens POLAK, F. L.: a.w., p. 8.

26) COETZEE, J. C.: a.w., p. 4

27) STOKER, H. G.: a.w., p. 20.

28) Vgl. DIEPENHORST, I. A.: a.w., p. 22.

29) Vgl, STOKER, H. G.: a.w., p. 17 e.v.

30) TEALE, A. E.: Keele - the first phase, art. in Universiteit en Hogeschool, Jan. 1963, nr. 3, jaargang 9, p. 160.

31) University of Keele, prospectus 1963-64, Printed by Hill \& Ainsworth Ltd., Stoke-on-Trend, p. 25.

32) University of Keele, prostectus 1963-64, p. 26.

33) Idem.

34) The University of Sussex, prospectus 1962-1963, Printed by The Dolphin Press Ltd., Brighton, p. 13.

35) KNELLER, G. F.: Higher learning in Britain, University of California Press, Berkeley and Los Angeles/Cambridge University Press, London, 1955, p. 185.

36) LOUET-FEISSER, J. J.: Wetenschap in toga; vakspecialisme en wijsgerige eenheid in de toekomstige universiteit, N.V. A. Oosthoek's Uitgeversmaatschappij, 1962, p. 58.

37) Vgl. supra, punt 4.

38) Vgl. DOOYEWEERD, H.: In the Twilight of Western Thought; studies in the pretended autonomy of philosophical thought. The Presbyterian and Reformed Publishing Company, Philadelphia, Pennsylvania, 1960, p. 180 e.v.; p. 1 e.v.; p. 113 e.v.

39) Vgl. die opskrif van punt 4.

40) In hierdie verband is dit waarskynlik 'n vergissing as die 
Verslag van die rektor oor die werksaamhede van die Potchefstroomse Universiteit vir Christelike Hoër Onderwys vir die tydperk van 1 Jan.-31 Des. 1963, gedruk deur die Potchefstroomse Herald (Edms.) Bpk., Potchefstroom, s.d. op p. 44 die volgende stel: „Studium Universale vorm 'n afdeling van die departement Wysbegeerte".

41) Vgl. REDAKSIONEEL: Studeer ons vir werkloses? art. in Perspektief, Jaargang II, nr. 4, Maart 1964, Potchefstroom, p. 1 e.v.

42) In Engeland is tans (alhoewel afnemend) 'n diskussie aan die gang oor die vraag of die facultas artium die waarborg van die idee van die gentleman (,,as a cultured man" wat nie 'n spesialis is nie, maar tog 'n leier) is en of die natuurwetenskappe (sciences) ons voorsien van die nodige kennis vir 'n tegniese eeu.

Vgl. in hierdie verband SNOW, C. P.: The two cultures and the scientific revolution, The Rede Lecture, Cambridge University Press, London etc., 1962" (c1959).

LEAVIS, F. R.: Two cultures? The significance of C. P. Snow, ... being the Richmond Lecture, 1962, with an essay on Sir Charles Snow's Rede Lecture by Michael Yudkin; Chatto \& Windus, London, 1962.

TRILLING, L.: Science, literature and culture; a comment on the Leavis-Snow controversy, art. in Universities Quarterly, vol. 7, no. 1, Dec. 1962. 